\title{
Small Molecules in the Treatment of Squamous Cell Carcinomas: Focus on Indirubins
}

\author{
Mirijam Schäfer ${ }^{1} \mathbb{D}$, Marie Luise Semmler ${ }^{1}$, Thoralf Bernhardt ${ }^{1}$, Tobias Fischer ${ }^{1}$, Vinodh Kakkassery ${ }^{2}{ }^{\mathbb{D}}$, \\ Robert Ramer ${ }^{3}$, Martin Hein ${ }^{4}$, Sander Bekeschus ${ }^{5}{ }^{\circ}$, Peter Langer ${ }^{4}$, Burkhard Hinz ${ }^{3}$, Steffen Emmert ${ }^{1}$ \\ and Lars Boeckmann $1, * \mathbb{0}$
}

1 Clinic and Policlinic for Dermatology and Venereology, University Medical Center Rostock, 18057 Rostock, Germany; mirijam.schaefer@med.uni-rostock.de (M.S.); luise.semmler@med.uni-rostock.de (M.L.S.); thoralf.bernhardt@med.uni-rostock.de (T.B.); tobias.fischer@med.uni-rostock.de (T.F.); steffen.emmert@med.uni-rostock.de (S.E.)

2 Department of Ophthalmology, University of Lübeck, 23562 Lübeck, Germany; vinodh.kakkassery@uni-luebeck.de

3 Institute for Pharmacology and Toxicology, University Medical Center Rostock, 18057 Rostock, Germany; robert.ramer@med.uni-rostock.de (R.R.); burkhard.hinz@med.uni-rostock.de (B.H.)

4 Institute for Chemistry, University Rostock, 18059 Rostock, Germany; martin.hein@uni-rostock.de (M.H.); peter.langer@uni-rostock.de (P.L.)

5 ZIK Plasmatis, Leibniz-Institute for Plasma Science and Technology (INP), 17489 Greifswald, Germany; sander.bekeschus@inp-greifswald.de

* Correspondence: lars.boeckmann@med.uni-rostock.de

check for updates

Citation: Schäfer, M.; Semmler, M.L.; Bernhardt, T.; Fischer, T.; Kakkassery, V.; Ramer, R.; Hein, M.; Bekeschus, S.; Langer, P.; Hinz, B.; et al. Small Molecules in the Treatment of Squamous Cell Carcinomas: Focus on Indirubins. Cancers 2021, 13, 1770. https://doi.org/10.3390/

cancers 13081770

Academic Editor: Ralf Gutzmer

Received: 10 March 2021

Accepted: 28 March 2021

Published: 7 April 2021

Publisher's Note: MDPI stays neutral with regard to jurisdictional claims in published maps and institutional affiliations.

Copyright: (c) 2021 by the authors. Licensee MDPI, Basel, Switzerland. This article is an open access article distributed under the terms and conditions of the Creative Commons Attribution (CC BY) license (https:// creativecommons.org/licenses/by/ $4.0 /)$.
Simple Summary: In this review, the genetic landscape of squamous cell carcinoma is related to the potential targets of indirubin-based small molecules in cancer therapy. Being a component of traditional Chinese medicine, indirubins are used to treat chronic or inflammatory diseases, and have received increasing attention in cancer treatment due to their proapoptotic and antiproliferative activity. Frequent genetic alterations of squamous cell carcinomas are summarized, and it is discussed how these may render tumors susceptible to indirubin-based small molecule inhibitors.

Abstract: Skin cancers are the most common malignancies in the world. Among the most frequent skin cancer entities, squamous cell carcinoma (SCC) ranks second ( $20 \%)$ after basal cell carcinoma $(\sim 77 \%)$. In early stages, a complete surgical removal of the affected tissue is carried out as standard therapy. To treat advanced and metastatic cancers, targeted therapies with small molecule inhibitors are gaining increasing attention. Small molecules are a heterogeneous group of protein regulators, which are produced by chemical synthesis or fermentation. The majority of them belong to the group of receptor tyrosine kinase inhibitors (RTKIs), which specifically bind to certain RTKs and directly influence the respective signaling pathway. Knowledge of characteristic molecular alterations in certain cancer entities, such as SCC, can help identify tumor-specific substances for targeted therapies. Most frequently, altered genes in SCC include TP53, NOTCH, EGFR, and CCND1. For example, the gene CCND1, which codes for cyclin D1 protein, is upregulated in nearly half of SCC cases and promotes proliferation of affected cells. A treatment with the small molecule $5^{\prime}$-nitroindirubinmonoxime (INO) leads to inhibition of cyclin D1 and thus inhibition of proliferation. As a component of Danggui Longhui Wan, a traditional Chinese medicine, indirubins are used to treat chronic diseases and have been shown to inhibit inflammatory reactions. Indirubins are pharmacologically relevant small molecules with proapoptotic and antiproliferative activity. In this review, we discuss the current literature on indirubin-based small molecules in cancer treatment. A special focus is on the molecular biology of squamous cell carcinomas, their alterations, and how these are rendered susceptible to indirubin-based small molecule inhibitors. The potential molecular mechanisms of the efficacy of indirubins in killing SCC cells will be discussed as well.

Keywords: indirubins; small molecules; squamous cell carcinoma 


\section{Introduction}

Skin cancers are the most common malignancies in the world. Among the most frequent skin cancer entities, squamous cell carcinoma (SCC) ranks second ( 20\%) after basal cell carcinoma $(\sim 77 \%)$ [1]. While basal cell carcinomas rarely metastasize $(0.0028-0.55 \%$ [2]), SCC spreads in about 5\% [3] of the cases. Standard therapy of early-stage SCC (stadium I and II) $[4,5]$ is the complete surgical removal of the tumor, frequently accompanied by removing the sentinel lymph nodes to prevent metastasis. If surgical removal is not possible, there are different therapeutic options, such as cryotherapy or local immunotherapy, chemotherapy or radiation therapy $[5,6]$. Patients with locally advanced SCC (stage III and IVa/b) are in most cases treated sequentially with platinum-based chemotherapy with or without induction chemotherapy [4,5]. Due to frequent side effects, caused by toxicity of some chemotherapeutic agents to healthy cells $[7,8]$ or the risk of infection during surgery, targeted therapies are gaining attention. For example, receptor tyrosine kinase (RTK) inhibitors are used to target tumor cells specifically. Lapatinib (Tykerb ${ }^{\circledR}$, GlaxoSmithKline, London-Brentford, UK) is such an inhibitor targeting the receptor tyrosine kinase and EGFR-member ErbB2 to treat breast cancer (BC). In the ALTERNATIVE study, Lapatinib was tested in combination with the monoclonal antibody Trastuzumab (Herceptin ${ }^{\circledR}$, Hoffmann-La Roche, Basel, Switzerland) and an aromatase inhibitor (AI) versus Trastuzumab + AI [9]. The progression-free survival (PFS) increased in the Lapatinib combination to 11 months versus 5.6 months in the Trastuzumab + AI group (HR $0.62(95 \% \mathrm{Cl} 0.45-0.88)$ ) [9]. A combination of Lapatinib with AI alone resulted in a PFS of 8.3 months (HR $0.85(95 \% \mathrm{Cl} 0.62-1.17)$ ) [9]. Because EGFR is overexpressed in a lot of SCC cases, there are even studies using short-term Lapatinib for the treatment of actinic keratosis (AK) and cutaneous SCC [10]. The treatment resulted in tumor regression in 2 out of 8 patients and a reduced AK in 7 out of 8 patients [10]. Frequently altered signaling pathways in cancers are involved in proliferation, migration, invasion and metastasis, angiogenesis, and apoptosis [11]. One way to target these pathways for therapeutic purposes is through the use of these small molecule inhibitors.

As a component of Danggui Longhui Wan, a traditional Chinese medicine, indirubins are used to treat chronic diseases [12] and have been shown to inhibit inflammatory reactions [13,14]. Indirubins are pharmacologically relevant small molecules with proapoptotic and antiproliferative activity. The first molecules based on indirubins appeared in literature in the 1980s $[15,16]$. The number of publications about indirubins in cancer therapy increased slightly until the 1990s, stagnated for almost ten years, and received more attention in cancer research since the 2000s. Indirubins have been shown to inhibit DNA synthesis, protein kinases [17-19], and cyclin-dependent kinases [19]. Therefore, they intervene directly with signaling pathways frequently altered in cancer cells and, thus, have the potential to prevent tumor cell proliferation and augment cytotoxicity.

In this review, we discuss the current literature on indirubin-based small molecules in cancer treatment. A particular focus is on the molecular biology of squamous cell carcinomas, their alterations, and how this may render these tumors particularly susceptible to indirubin-based small molecule inhibitors. Potential molecular mechanisms of indirubins-induced toxicity in cancer cells will be discussed.

\section{Small Molecules}

The term small molecule is generally imprecisely defined, so the term is used in many areas. Generally, sources state that small molecules are a heterogeneous group of active molecules with a maximum weight of $900 \mathrm{~g} / \mathrm{mol}$ [20]. They are produced by chemical synthesis or fermentation [21] and characterized by various biological functions. These include signal transduction, as a medicinal product or pesticide. About $2 \%$ of small molecules are so small that they can cross the blood-brain barrier, allowing indirubin-based drugs to be effective against insomnia, depression, or schizophrenia [22]. Small molecular compounds are also gaining in importance for targeted tumor treatments [23], which will be discussed in more detail below. 


\section{Mode of Action of Small Molecules and Potential Targets in Cancer}

Depending on the class of substance, small molecules have the property of inhibiting or activating specific intracellular signaling pathways [24-26], leading to reactivation of apoptosis mechanisms in cancer cells [27]. 58 human RTKs are known to play a key role in oncogenesis [28] and many small molecules target RTKs. RTK inhibitors are divided into five groups: type I inhibitors are noncovalent ATP-competitive inhibitors that link to active conformation [29]; type II inhibitors are nonselective by remaining in their inactive conformation and binding next to the ATP-binding site of inactive kinases [29]; in contrast, type III inhibitors are highly selective binding an allosteric site, remote from ATP site [29,30]; type IV RTKIs reversibly bind to the substrate-binding site of the kinase; type V inhibitors bind covalently and irreversibly to the active center of the kinase [29].

Meanwhile several small molecule RTKIs are approved as monotherapy or in combination therapies and provide favorable risk-to-benefit profiles compared to other therapies, such as cytostatic or radiation therapies $[25,26]$. Following the identification of the activating BRAF-V600 mutation in melanoma, the BRAF targeting small molecule Vemurafenib was approved for cancer treatment by the Federal Drug Administration (FDA) in 2011. A phase 3, randomized open-labeled study named BRIM-3 assessed the effects of Vemurafenib on patients with BRAF-V600E- and BRAF-V600K-positive melanoma in comparison to the cytostatic Dacarbazine [31]. This study revealed a median overall survival of 13.6 months (95\% $\mathrm{Cl} 12.5-15.2)$ in the Vemurafenib group versus 9.7 months $(95 \% \mathrm{Cl} 7.9-12.8)$ in the Dacarbazine group [31]. The median progression-free survival was 6.9 months $(95 \% \mathrm{Cl}$ 6.1-7.0) in the Vemurafenib group versus 1.6 months (95\% Cl 1.6-2.1) in the Dacarbazine group [31]. IMspire150 was another phase 3, randomized open-labeled study dealing with BRAF-V600-positive melanoma patients treated with Vemurafenib and the mitogen activated protein kinase (MEK)-inhibitor Cobimitinib with and without addition of the monoclonal programmed cell death ligand 1 (PD-L1) antibody Atezolizumab [32]. The combination of both inhibitors with the antibody therapy improved progression-free survival from 10.6 months to 15.1 months (Hazard ratio $0.78 ; 95 \%$ CI $0.63-0.97 ; p=0.025$ ) [32]. Gutzmer and colleagues interpreted the addition of Atezolizumab to targeted therapy with Vemurafenib and Cobimetinib as "safe and tolerable and significantly increased progression-free survival in patients with BRAFV600 mutation-positive advanced melanoma" [32]. These examples demonstrate that identifying tumor-specific mutations, and the development of small molecules that specifically target these alterations to restore the disturbed signaling pathway, is a promising strategy for precision cancer therapy.

Targeting genetic alterations is one of four tracks (genetics track) for targeted cancer therapies described by Benson and colleagues (Table 1) [33]. Gene mutations, and stable changes in expression across multiple cell divisions in cancer cells, are used to target and eliminate exactly these cells. The synergy track aims to restore apoptotic signaling pathways or induce synthetic lethality by targeting a mechanism in the cell that became essential, due to defects in another mechanism. An example for inducing synthetic lethality using small molecules is the poly(ADP-ribose)-polymerase (PARP) inhibitor DDHCB for the treatment of patients with breast cancer gene (BRCA) mutations [34]. BRCA plays a role in DNA double-strand break (DSB) repair through homologous recombination (HR). Inhibition of PARP (plays a role in base excision repair (BER)) leads to an increase of DSBs, which subsequently overwhelms the repair capacity of the homologous recombination pathway [35]. Consequently DSBs can only be repaired by error-prone non-homologous end joining (NHEJ) [35]. Hence, the defect in HR combined with BER inhibition leads to errors in DSB repair and subsequently to the induction of apoptosis. According to Benson and colleagues [33] (Table 1), the third track is the lineage track. This track aims at dependencies of cancer cells on tissue and cell type-specific survival factors, e.g., the microphthalmia-associated transcription factor (MITF)-inhibitor ML329, described by Faloon and colleagues [36] (Table 1). The last track Benson and colleagues describe is the host track. Inhibition or disturbance of the tumor environment leads to growth inhibition or starvation of the cancer cells. For example, the vascular endothelial growth factor 
receptor (VEGFR)- and rapidly accelerated fibrosarcoma-1 (Raf-1)-inhibitor Sorafenib inhibits angiogenesis in renal cancer cells and has been shown to partially stabilize the disease or shrink the tumor [37].

Comprehensive knowledge of impaired functions in specific tumors crucial for carcinogenesis allows the development of drugs that specifically target these functions in different tracks (Table 1). Hence, genetic analyses of different cancer entities provide the basis for specific targeted therapies using small molecules.

Table 1. Different tracks for targeted therapies using small molecules according to Benson et al. [33].

\begin{tabular}{|c|c|c|}
\hline Target & Background & Example \\
\hline $\begin{array}{l}\text { Genetics } \\
\text { track }\end{array}$ & $\begin{array}{l}\text { Stable changes in DNA (gene mutation and expression) } \\
\text { across multiple cell divisions }\end{array}$ & $\begin{array}{l}\text { BRAF-MEK-Inhibitors } \\
\text { e.g., Vemurafenib } \\
\text { (PLX4032) }[31,37,38]\end{array}$ \\
\hline $\begin{array}{c}\text { Synergy } \\
\text { track }\end{array}$ & $\begin{array}{l}\text { Restoring apoptotic signaling pathways or inducing } \\
\text { synthetic lethality by targeting mechanism that became } \\
\text { essential due to defects in another mechanism }\end{array}$ & $\begin{array}{c}\text { PARP-Inhibitors for } \\
\text { patients with } B R C A \\
\text { mutation } \\
\text { e.g., DDHCB } \\
{[34]}\end{array}$ \\
\hline $\begin{array}{l}\text { Lineage } \\
\text { track }\end{array}$ & Inhibition of tissue and cell type-specific survival factors & $\begin{array}{l}\text { MITF-Inhibitors } \\
\text { e.g., ML329 } \\
{[36]}\end{array}$ \\
\hline $\begin{array}{l}\text { Host } \\
\text { track }\end{array}$ & $\begin{array}{l}\text { Inhibition/disturbance of the tumor environment } \\
\text { (inhibition of angiogenesis) }\end{array}$ & $\begin{array}{c}\text { VEGFR-Inhibitors } \\
\text { e.g., Sorafenib (BAY } \\
\text { 43-9006) } \\
\text { [37] }\end{array}$ \\
\hline
\end{tabular}

\section{Molecular Biology of Squamous Cell Carcinoma}

In this review, we focus in particular on genetic alteration frequently observed in squamous cell carcinomas of the skin (SCC). Most frequently, mutated or misregulated in SCC are the tumor suppressor protein gene TP53, downregulated in $42-90 \%$ of SCC cases [39-42] and NOTCH, downregulated in 22-86\% of cases [39,43-46] (Table 2). The protein p53 normally ensures a cell cycle arrest by inhibiting the cyclin D/CDK4/6- and the cyclin E/CDK2-complex if the cell is damaged and initiates apoptosis by activating b-cell lymphoma-2 (Bcl-2)-genes [47]. A mutation or loss of function of TP53 may lead to uncontrolled cell growth and cancer. $\mathrm{NOTCH}$ is a transmembrane protein that forms a complex with other proteins leading to the induction of NOTCH-response genes such as hairy and enhancer of slit-related genes (HESR) [48], cellular myelocytomatosis (c-Myc) [49,50], cyclin D1 (CCND1) [51], cyclin D3 (CCND3) [52], cyclin-dependent kinase 5 (CDK5) [50], the cyclin-dependent kinase (CDK)-inhibitor $p 21$ [53], the zinc finger protein family snail gene (SNAI1) [54] and the platelet-derived growth factor receptor $\beta$ gene (PDGFR $\beta$ ) [55]. These NOTCH-response genes are involved in proliferation, cell differentiation and angiogenesis. The negative regulator of NOTCH and proliferation factor EGFR is overexpressed in 43-95\% of SCC tumors [56-61] (Table 2). EGFR is a transmembrane receptor with intrinsic tyrosine kinase activity. It is activated by dimerization of EGF and TGF $\alpha$, which activates signaling molecules such as signal transducers and activators of transcription (STAT), protein kinases $\mathrm{B}(\mathrm{Akt} / \mathrm{PKB})$, and MEK and leads to the stimulation of cell growth and the prevention of apoptosis [62]. The gene CCND1, overexpressed in $30-50 \%$ of SCC cases [63-65], encodes the cyclin D1 protein. Cyclins act as regulators for cyclin-dependent kinases (CDKs). Cyclin D1, in particular, forms a complex with CDK4 or CDK6 and acts as their regulatory subunit [66-68]. The complex monophosphorylates and activates the retinoblastoma protein $(\mathrm{pRb})$ in DNA damage response [69]. The monophosphorylated $\mathrm{pRb}$ then binds the transcription factor E2F, which leads to a cell cycle arrest in the G1phase [69]. The activation of the cyclin E/CDK2 complex at the late G1 restriction point hyper phosphorylates and inactivates $\mathrm{pRb}, \mathrm{E} 2 \mathrm{~F}$ is split off, and the cell cycle continues in the S-phase. 
A loss of function of CDKN2A (cyclin-dependent kinase inhibitor 2A), which codes for two proteins, is frequently observed in SCC (28\%; Table 2$)[40,70,71]$. One protein CDKN2A encodes for is the INK4 member p16. This tumor suppressor regulates the cell cycle by inhibiting CDK4 and CDK6, thereby preventing phosphorylation and activation of $\mathrm{pRb}$. Inactive $\mathrm{pRb}$ is not bound to E2F and the cell cycle continues [69]. A feedback loop is generated in which the expression of $\mathrm{p} 16$ is controlled by the retinoblastoma proteins [72,73]: the $\mathrm{pRb}-\mathrm{E} 2 \mathrm{~F}$ complex inhibits the expression of p16, less p16 inhibits the cyclin D1/CKD4/6 complex and more active $\mathrm{pRb}$ binds E2F. The $\mathrm{p} 16 / \mathrm{Rb}$ signaling pathway collaborates with the mitogenic signaling cascade to induce reactive oxygen species, which activate the protein kinase $C$ delta and lead to an irreversible cell cycle stop [74,75]. The other protein encoded by the CDKN2A gene is p14ARF. This protein activates the tumor suppressor p53, induces cell cycle arrest in the G2 phase and subsequent apoptosis [76]. In addition, p14ARF is said to downregulate E2F-dependent transcription and would therefore also play a role in controlling the G1/S transition [77]. The gene for transforming growth factorbeta receptors (TGFBR) encodes for serine/threonine kinase receptors, which are involved in cell differentiation [78] and apoptosis [79]. A loss of TGFBR, observed in 43\% of SCC cases [46] (Table 2), leads to increased proliferation of the cells [80]. The next gene is HRAS (Harvey rat sarcoma), which encodes for the GTPase HRAS and is upregulated in 6-38\% of SCC cases (Table 2). It plays a role in cell growth, division and survival by regulating the RAF/MAPK/ERK [81] and P13K/Akt pathway [82]. Kinetochore localized astrin/SPAG5 binding protein gene (KNSTRN) encodes for a protein responsible for modulation of anaphase onset and chromosome segregation during mitosis [40]. In SCC patients, KNSTRN is mutated in 17-19\% of cases and is associated with controlling chromosomal activity in normal and cancerous cells $[40,83]$. Lee and colleagues (2014) examined recurrent point mutations in the KNSTRN gene in cutaneous squamous cell carcinomas by sequencing, and sequencing libraries in vitro and in vivo. They show mutant KNSTRN disrupts chromatid cohesion required for faithful chromosome segregation, driving cells toward aneuploidy and leading to tumor development [40].

Table 2 summarizes the discussed, most frequently observed genetic alterations in squamous cell carcinomas. The growing understanding of such genetic alterations underlying carcinogenesis, and the further development of various methods for small molecule synthesis, allows the generation of an ever-broader spectrum of potentially active molecules. Once the defective genes are known, existing and novel small molecules can be screened for molecules that target these altered pathways and selectively eliminate the cancer cells.

Table 2. Frequently altered genes in squamous cell carcinomas.

\begin{tabular}{ccc}
\hline Gene & Altered in SCC & Reference \\
\hline \multirow{2}{*}{ TP53 } & $42-90 \% \downarrow$ & Nakazawa et al. (1994) [42] \\
& Mutation & Giglia-Mari et al. (2003) [41] \\
& & Lee et al. (2014) [40] \\
& & Inman et al. (2018) [39] \\
& & Stransky et al. (2011) [43] \\
NOTCH & S2-86\% $\downarrow$ & South et al. (2012) [44] \\
& & South et al. (2014) [45] \\
& & Cammareri et al. (2016) [46] \\
& & Inman et al. (2018) [39] \\
& & Rodeck et al. (1997) [56] \\
& & Ang et al. (2002) [58] \\
& & Kaliankrishna et al. (2006) [61] \\
& Overexpression & Fogarty et al. (2007) [59] \\
& & Kolev et al. (2008) [60] \\
& & Uribe et al. (2011) [57]
\end{tabular}


Table 2. Cont.

\begin{tabular}{ccc}
\hline TGFBR & $\begin{array}{c}43 \% \downarrow \\
\text { Mutation/Loss }\end{array}$ & Cammareri et al. (2016) [46] \\
& & Bamford et al. (2004) [84] \\
HRAS & $6-38 \% \uparrow$ & Durinck et al. (2011) [85] \\
& & South et al. (2014) [45] \\
& Lee et al. (2014) [40] \\
& & Cammareri et al. (2016) [46] \\
CDKN2A (p16INK4a) & Inman et al. (2018) [39] \\
& Mutation/Loss & Brown et al. (2004) [71] \\
KNSTRN & Bäckvall et al. (2005) [70] & Lee et al. (2014) [40] \\
& Mutation & Lee et al. (2014) [40] \\
\hline$\uparrow$ Activation $\downarrow$ Inactivation & &
\end{tabular}

$\uparrow$ Activation $\downarrow$ Inactivation.

\section{Small Molecules Based on Indirubins in the Treatment of SCC}

For some years now, indirubins have been a promising basic structure for synthesizing of new small molecules for cancer treatment. As a component of Danggui Longhui Wan, a traditional Chinese medicine, indirubins are used to treat chronic diseases [12] and have been shown to inhibit inflammatory reactions $[13,14]$. With regard to cancer, they have been shown to inhibit DNA synthesis, protein kinases [17-19], and cyclin-dependent kinases [19]. This means that they may interfere with frequently disturbed signaling pathways in SCC and thus provide good candidates to stop tumor cell growth. Specifically, this involves intervening in proliferation by inhibiting the dimerization and phosphorylation of the receptor tyrosine kinase c-Met to stop the subsequent signaling pathways P13K/Akt, RAS/MAPK, and STAT [86]. The tyrosine kinase receptor c-Met normally binds with hepatocyte growth factor (HGF) and triggers processes such as embryogenesis, cell growth, cell differentiation, and angiogenesis [87,88]. Yasui and colleagues [89] demonstrated in SCC-cells the induction of the formation of lammellipodia by c-Met signaling, which promotes migration. Ndolo and colleagues [90] tested the indirubin derivate LDD-1937 (5-Methoxycarbonylindirubin-3'(2-(1-piperazyl)ethyl)-oximether dihydrochloride; Figure 1) in gastric cancer cells SNU-638 (overexpress c-Met), which inhibits migration due to the lack of binding possibility of HGF. The binding possibility of HGF is also associated with the regulation of invasion and metastasis of tumors [91-94]. Treatment with LDD-1937 also decreased the expression of the Erk1/2, STAT3, STAT5, and Akt (downstream proteins of c-Met) as well as cyclin B1 and CDK2, leading to reduced cell viability, colony formation, and cell cycle arrest in the G2/M phase [90]. Finally, apoptosis was induced, evident by increased cleavage of PARP after treatment with LDD-1937 [90].

Another point of attack is the inhibition of EGFR. It is frequently overexpressed in SCC (Table $2[56,57,59,60])$ and involved in proliferation and apoptosis [62]. The inhibition by AG1478 and Cetuximab suppresses migration and invasion in tongue SCC cells SAS and gingival SCC cells CA9-22. It was also shown that the migration of SCC cells is negatively influenced by inhibition of Wnt5a [91,93], which is strongly expressed in nonmelanoma skin cancer [91]. Pourreyron and colleagues showed that Wnt5a is forming active gradients, while canonical Wnt signaling is repressed [91]. The inhibition of Wnt5a and the activation of the canonical Wnt signaling pathway provide further potential targets of an indirubin-based small molecule therapy. Park and colleagues found that the indirubin INO (5-Nitroindirubin-3'-oxime, Figure 1 ) as well as bromindirubin-3-oxime, could be an activator of Wnt (Figure 2) and the associated canonical $\beta$-catenin-mediated signaling path, similar to what has been observed for [95]. 


\section{Indirubin and its derivates}

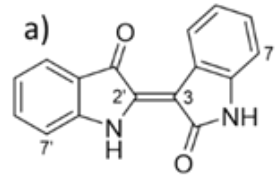

Indirubin

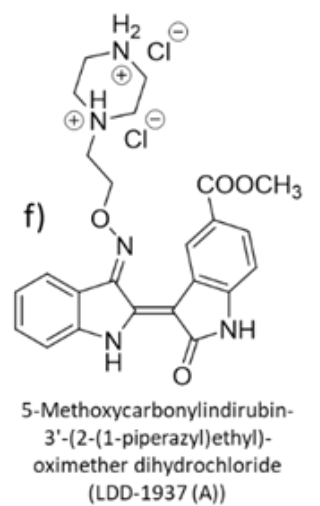

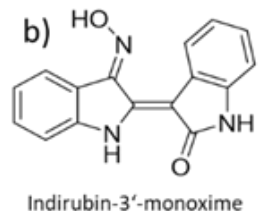

Indirubin-3'-monoxime

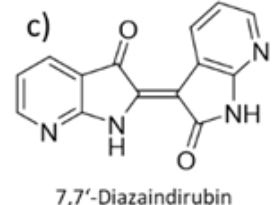

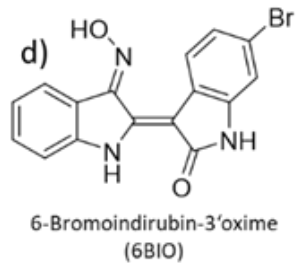

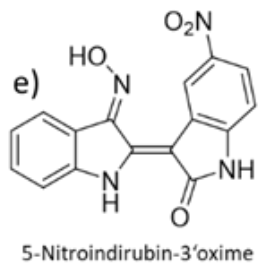

(INO)

Figure 1. Indirubine and its derivates. (a) Indirubin; (b) Indirubin-3'-monoxime; (c) 7,7'-Diazaindirubin; (d) 6-Bromoindirbun3'-oxime (6BIO); (e) 5-Nitroindirubin-3'oxime (INO); (f) 5-Methoxycarbonylindirubin-3'-(2-(1-piperazyl)ethyl)-oximether dihydrochloride (LDD-1937 (A)); (g) substituted indirubin-3'-oximethers: Indirubin-3'-(2-(2-hydroxyethoxy)ethyl)-oximether (E564), 5-Methoxyindirubin-3'-oxime (E728), Indirubin-3'-(3,4-dihydroxybutyl)-oximether (E804), 5-Methoxyindirubin-3'-(2,3dihydroxypropyl)-oximether (E738).

Furthermore, treatment of human breast and prostate cancer cells with the indirubin derivates E564 (Indirubin-3'-(2-(2-hydroxyethoxy)ethyl)-oximether, Figure 1), E728 (5-Methoxyindirubin-3'-oxime, Figure 1), and E804 (Indirubin-3'-(3,4-dihydroxybutyl)oximether, Figure 1) showed STAT3 inhibition leading to decreased growth [96] and induction of apoptosis (Figure 2 [96-98]). E738 (5-Methoxyindirubin-3'-(2,3-dihydroxypropyl)oximether, Figure 1) has been identified as inhibitor of janus and src family kinases, observed in human pancreatic cancer cells (Panc-1, MIA-PC2, BXPC3, AsPC1) [18]. Inhibition of these kinases leads to the inhibition of STAT3 and subsequently reduces proliferation and induces apoptosis [18]. These indirubin derivates have not been tested in SCC cells so far, but since EGFR, which activates STAT3, is frequently overexpressed in SCC (Table 2), targeting STAT3 may provide a promising approach for SCC treatment as well. STAT3 normally induces the expression of downstream targets $B c L-2, b$-cell lymphoma $x L(B c l-x L)$, induced myeloid leukemia cell differentiation protein gene (Mcl-1), c-Myc, surviving, and CCND1 [99]. Bcl-2, Bcl-xL, and Mcl-1 are antiapoptotic proteins of the Bcl-2 protein family [100]. Bcl-2 and $\mathrm{Bcl}-\mathrm{xL}$ control mitochondrial membrane permeability and the release of cytochrome c, which modulates apoptosis [101]. Therefore, inhibition of STAT3 also reduces the level of Bcl-xL. As a consequence of missing Bcl-xL, the mitochondrial membrane potential destabilizes, cytochrome c gets released, and apoptosis is induced (Figure 2 [102,103]). Mcl-1 is an exceptional player of Bcl-2 family. A loss of function of Mcl-1 has the most dramatic impact on cell survival of different cell types [100]. Another downstream target is $c-M y c$. MYC is a transcription factor, which affects regulation of most active human genes in the cell without any particular preference [104]. Mutated MYC is an oncogene because it can permanently upregulate the expression of certain genes [105-109]. Overexpression of survivin in cancer cells is associated with a significantly reduced survival rate of the affected patients $[56,59,65]$, a higher likelihood of recurrence, and a reduced rate of apoptosis in tumor cells. The last downstream target of STAT3 mentioned here is CCND1, which is overexpressed in up to 50\% of SCC tumors (Table 2 [63-65]) and 
encodes for cyclin D1. It is involved in the transition from G1 phase to S phase of the cell cycle [66-68] by binding CDK4/6 and phosphorylating pRb. Kim and colleagues [110] reported that $5^{\prime}$-nitroindirubin-monxime (INO, Figure 1) inhibits the proliferation of human SCC cells (KB cells) by reducing CDK4 and cyclin D1/cyclin D3 levels leading to cell cycle arrest in the G1/S phase and by reducing the activity of cyclin-dependent kinase $2 /$ cyclin B complex, which induces a cell cycle arrest in G2/M phase. Indeed, Akiyama and colleagues [111] showed that STAT3 inhibition by STAT shRNA-4 caused suppression of tumor growth and induction of apoptosis by upregulation of tumor suppressor latexin in highly STAT3-activated SCC-3 cells.

Like inhibition of STAT3, the inhibition of glycogen synthase kinase 3 (GSK3) by $\left(2^{\prime} \mathrm{Z}, 3^{\prime} \mathrm{E}\right)$-6-bromoindirubin-3'-oxime (6BIO; Figure 1), as shown in Figure 2, also reduces the expression of MYC in human embryonic fibroblasts cells [112]. By using $6 \mathrm{BIO}$ in combination with doxorubicin (DXT) for treatment of human newborn foreskin (BJ cells) and human lung embryonic fibroblasts (IMR90 cells) Sklirou and colleagues demonstrated a reduced activation of p53 and less $\gamma \mathrm{H} 2 \mathrm{AX}$ phosphorylation than by using DXT alone.

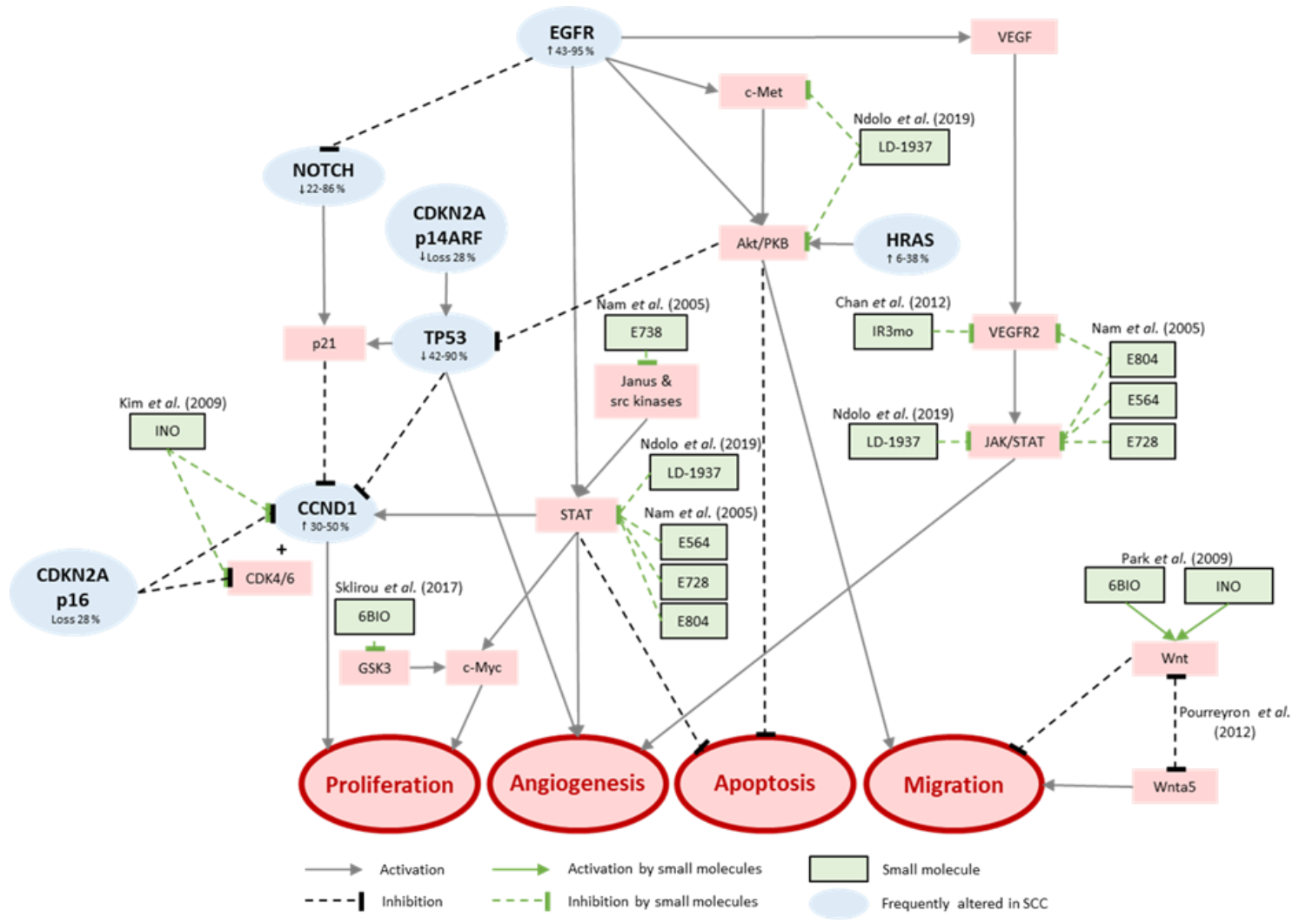

Figure 2. Indirubins interacting with signaling pathways frequently altered in squamous cell carcinoma of the skin.

Besides their impact on proliferation, migration, and apoptosis, indirubin and its derivates indirubin-3'-monoxime (IR3mo; Figure 1) and E804) also decrease angiogenesis by inhibiting VEGFR2-dependent JAK/STAT3 signaling [13,113]. By preventing VEGFR2 phosphorylation at two phosphorylation sites [39]. It was also shown that the NOTCH gene, which is crucial for angiogenesis and mutated in SCCs in 22-86\% of cases (Table $2[39,43-46]$ ), is activated by c-Met signaling. Consequently, inhibition of c-Met also leads to reduced NOTCH activity, ultimately reducing angiogenesis. Direct inhibition of NOTCH1 by IR3mo has already been demonstrated [114], as well as inhibition of DRAK2 (DAP kinase-related apoptosisinducing protein kinase 2) [12]. Jung and colleagues identified indirubin-3-monoximes by a high throughput screening campaign, in which 16 potent indirubin-based inhibitors were found to inhibit DRAK2 [12]. It belongs to the superfamily of death-associated protein kinase (DAPK)-family and serves to set the initial threshold for thymic and peripheral T-cell acti- 
vation and later, to maintain the survival of effector T cells [115,116]. Moreover, it has been shown that ectopic expression of DRAK2 in cell lines induces apoptosis [117,118].

Finally, Cheng and colleagues identified 7,7-Diazaindirubin (Figure 1) as a cause of inhibition of casein kinase 2 in LXFL529L cells (human large cell lung tumor xenograft). It exhibited markedly enhanced growth inhibitory activity in these cells [119]. This substance also displayed antiproliferative activity in the National Cancer Institute (NCI) 60 cell line panel preferentially in certain melanoma and non-small cell lung cancer cells, according to Cheng et al. [119]. The casein kinase 2 has dual functionality, being involved in both cell growth and proliferation as well as apoptosis [120].

The above-described activities of several indirubin based small molecules and their role in inhibiting proliferation, angiogenesis, and/or migration as well as inducing apoptosis combined with knowledge on frequent molecular alterations in SCCs that lead to the activation of proliferation, angiogenesis, and/or migration as well as the inhibition of apoptosis suggest that indirubin derivates are promising candidates for SCC treatment. Hence, further studies assessing the molecular mechanisms of existing indirubin-based small molecules as well as of newly synthesized indirubin derivates are warranted.

\section{Conclusions}

This review summarizes frequently altered genes in SCC and shows how different indirubin derivates directly or indirectly interfere with these genes by inhibiting proteins downstream or upstream of the altered genes. Although some of the effects of indirubins are known, more research is needed to elucidate the molecular mechanisms of action. Knowledge of characteristic molecular alterations in certain cancer entities, such as those shown here for SCC, can help identify tumor-specific substances for targeted therapies. Indirubins show a broad spectrum of activity against SCC and, hence, provide a class of substances with further potential for targeted SCC therapies.

Funding: The joint research project "ONKOTHER-H" is supported by the European Social Fund (ESF), reference: ESF/14-BM-A55-0001/18 and 02/18 and 04/18 and 06/18, and the Ministry of Education, Science and Culture of Mecklenburg-Vorpommern, Germany. Furthermore, this project is supported by the Damp Stiftung. SE is also supported by the DFG (EM 68/13-1).

Institutional Review Board Statement: Not applicable.

Informed Consent Statement: Not applicable.

Data Availability Statement: Not applicable.

Conflicts of Interest: The authors declare no conflict of interest.

\section{References}

1. Bray, F.; Ferlay, J.; Soerjomataram, I.; Siegel, R.L.; Torre, L.A.; Jemal, A. Global cancer statistics 2018: GLOBOCAN estimates of incidence and mortality worldwide for 36 cancers in 185 countries. CA Cancer J. Clin. 2018, 68, 394-424. [CrossRef]

2. Rubin, A.I.; Chen, E.H.; Ratner, D. Basal-Cell Carcinoma. N. Engl. J. Med. 2005, 353, 2262-2269. [CrossRef]

3. Brantsch, K.D.; Meisner, C.; Schönfisch, B.; Trilling, B.; Wehner-Caroli, J.; Röcken, M.; Breuninger, H. Analysis of risk factors determining prognosis of cutaneous squamous-cell carcinoma: A prospective study. Lancet Oncol. 2008, 9, 713-720. [CrossRef]

4. Marur, S.; Forastiere, A.A. Head and Neck Cancer: Changing Epidemiology, Diagnosis, and Treatment. Mayo Clin. Proc. 2008, 83, 489-501. [CrossRef] [PubMed]

5. Pfister, D.G.; Ang, K.-K.; Brizel, D.M.; A Burtness, B.; Busse, P.M.; Caudell, J.J.; Cmelak, A.J.; Colevas, A.D.; Dunphy, F.; Eisele, D.W.; et al. Head and neck cancers, version 2.2013. Featured updates to the NCCN guidelines. J. Natl. Compr. Cancer Netw. 2013, 11,917-923. [CrossRef]

6. Leitlinienprogramm Onkologie (Deutsche Krebsgesellschaft, Deutsche Krebshilfe, AWMF): S3-Leitlinie Aktinische Keratose und Plattenepithelkarzinom der Haut, Langversion 1.1, 2020, AWMF Registernummer: 032/022OL. Available online: https: //www.leitlinienprogramm-onkologie.de/leitlinien/aktinische-keratosen-und-plattenepithelkarzinom-der-haut/ (accessed on 10 April 2020).

7. Dothager, R.S.; Putt, K.S.; Allen, B.J.; Leslie, B.J.; Nesterenko, V.; Hergenrother, P.J. Synthesis and Identification of Small Molecules that Potently Induce Apoptosis in Melanoma Cells through G1 Cell Cycle Arrest. J. Am. Chem. Soc. 2005, 127, 8686-8696. [CrossRef] [PubMed] 
8. Marur, S.; Forastiere, A.A. Head and Neck Squamous Cell Carcinoma: Update on Epidemiology, Diagnosis, and Treatment. Mayo Clin. Proc. 2016, 91, 386-396. [CrossRef] [PubMed]

9. Johnston, S.R.D.; Hegg, R.; Im, S.-A.; Park, I.H.; Burdaeva, O.; Kurteva, G.; Press, M.F.; Tjulandin, S.; Iwata, H.; Simon, S.D.; et al. Phase III, Randomized Study of Dual Human Epidermal Growth Factor Receptor 2 (HER2) Blockade With Lapatinib Plus Trastuzumab in Combination With an Aromatase Inhibitor in Postmenopausal Women With HER2-Positive, Hormone Receptor-Positive Metastatic Breast Cancer: Updated Results of ALTERNATIVE. J. Clin. Oncol. 2021, 39, 79-89. [CrossRef] [PubMed]

10. Jenni, D.; Karpova, M.; Mühleisen, B.; Mangana, J.; Dreier, J.; Hafner, J.; Dummer, R. A prospective clinical trial to assess lapatinib effects on cutaneous squamous cell carcinoma and actinic keratosis. ESMO Open 2016, 1, e000003. [CrossRef] [PubMed]

11. Wagener, C.; Müller, O. (Eds.) 8.5 Signalwege in Tumoren. In Molekulare Onkologie; Georg Thieme Verlag: Stuttgart, Germany, 2010.

12. Jung, M.E.; Byun, B.J.; Kim, H.-M.; Lee, J.Y.; Park, J.-H.; Lee, N.; Son, Y.H.; Choi, S.U.; Yang, K.-M.; Kim, S.-J.; et al. Discovery of indirubin derivatives as new class of DRAK2 inhibitors from high throughput screening. Bioorg. Med. Chem. Lett. 2016, 26, 2719-2723. [CrossRef]

13. Chan, Y.-K.; Kwok, H.-H.; Chan, L.-S.; Leung, K.S.-Y.; Shi, J.; Mak, N.-K.; Wong, R.N.-S.; Yue, P.Y.-K. An indirubin derivative, E804, exhibits potent angiosuppressive activity. Biochem. Pharmacol. 2012, 83, 598-607. [CrossRef]

14. Kunikata, T.; Tatefuji, T.; Aga, H.; Iwaki, K.; Ikeda, M.; Kurimoto, M. Indirubin inhibits inflammatory reactions in delayed-type hypersensitivity. Eur. J. Pharmacol. 2000, 410, 93-100. [CrossRef]

15. Hsu, B. The Use of Herbs in Anticancer Agents. Am. J. Chin. Med. 1980, 8, 301-306. [CrossRef] [PubMed]

16. Wu, G.Y.; Fang, F.D. Studies on the mechanism of indirubin action in the treatment of chronic granulocytic leukemia. II. Effects of indirubin on nucleic acid and protein synthesis in animal transplantable tumor cells and normal proliferating cells in vitro (author's transl). Zhongguo Yi Xue Ke Xue Yuan Xue Bao Acta Acad. Med. Sin. 1980, 2, 83-87. (In Chinese)

17. Choi, Y.L.; Soda, M.; Yamashita, Y.; Ueno, T.; Takashima, J.; Nakajima, T.; Yatabe, Y.; Takeuchi, K.; Hamada, T.; Haruta, H.; et al. EML4-ALK Mutations in Lung Cancer That Confer Resistance to ALK Inhibitors. N. Engl. J. Med. 2010, 363, 1734-1739. [CrossRef] [PubMed]

18. Nam, S.; Wen, W.; Schroeder, A.; Herrmann, A.; Yu, H.; Cheng, X.; Merz, K.-H.; Eisenbrand, G.; Li, H.; Yuan, Y.-C.; et al. Dual inhibition of Janus and Src family kinases by novel indirubin derivative blocks constitutively-activated Stat3 signaling associated with apoptosis of human pancreatic cancer cells. Mol. Oncol. 2012, 7, 369-378. [CrossRef]

19. Blažević, T.; Heiss, E.H.; Atanasov, A.G.; Breuss, J.M.; Dirsch, V.M.; Uhrin, P. Indirubin and Indirubin Derivatives for Counteracting Proliferative Diseases. Evid.-Based Complement. Altern. Med. 2015, 2015, 1-12. [CrossRef]

20. Dougherty, T.J.; Pucci, M.J. Antibiotic Discovery and Development; Springer: Boston, MA, USA, 2012.

21. Lu, B.; Atala, A. Chapter 6-Small Molecules: Controlling Cell Fate and Function. In In Situ Tissue Regeneration; Lee, S.J., Atala, A., Yoo, J., Eds.; Elsevier: Amsterdam, The Netherlands, 2016.

22. Pardridge, W.M. The blood-brain barrier: Bottleneck in brain drug development. NeuroRX 2005, 2, 3-14. [CrossRef]

23. Butowski, N.; Chang, S.M. Small Molecule and Monoclonal Antibody Therapies in Neurooncology. Cancer Control 2005, 12, 116-124. [CrossRef]

24. Cerchia, C. Small Molecule Drugs and Targeted Therapy for Melanoma: Current Strategies and Future Directions. Curr. Med. Chem. 2017, 24, 2312-2344. [CrossRef]

25. Malissen, N.; Grob, J.-J. Metastatic Melanoma: Recent Therapeutic Progress and Future Perspectives. Drugs 2018, 78, 1197-1209. [CrossRef]

26. Strickland, L.R.; Pal, H.C.; Elmets, C.A.; Afaq, F. Targeting drivers of melanoma with synthetic small molecules and phytochemicals. Cancer Lett. 2015, 359, 20-35. [CrossRef] [PubMed]

27. Djehal, A.; Krayem, M.; Najem, A.; Hammoud, H.; Cresteil, T.; Nebigil, C.G.; Wang, D.; Yu, P.; Bentouhami, E.; Ghanem, G.E.; et al. Targeting prohibitin with small molecules to promote melanogenesis and apoptosis in melanoma cells. Eur. J. Med. Chem. 2018, 155, 880-888. [CrossRef]

28. Lemmon, M.A.; Schlessinger, J. Cell Signaling by Receptor Tyrosine Kinases. Cell 2010, 141, 1117-1134. [CrossRef]

29. Pottier, C.; Fresnais, M.; Gilon, M.; Jérusalem, G.; Longuespée, R.; Sounni, N.E. Tyrosine Kinase Inhibitors in Cancer: Breakthrough and Challenges of Targeted Therapy. Cancers 2020, 12, 731. [CrossRef]

30. Fabbro, D.; Cowan-Jacob, S.W.; Moebitz, H. Ten things you should know about protein kinases: IUPHAR Review 14. Br. J. Pharmacol. 2015, 172, 2675-2700. [CrossRef] [PubMed]

31. A McArthur, G.; Chapman, P.B.; Robert, C.; Larkin, J.; Haanen, J.B.; Dummer, R.; Ribas, A.; Hogg, D.; Hamid, O.; A Ascierto, P.; et al. Safety and efficacy of vemurafenib in BRAFV600E and BRAFV600K mutation-positive melanoma (BRIM-3): Extended follow-up of a phase 3, randomised, open-label study. Lancet Oncol. 2014, 15, 323-332. [CrossRef]

32. Gutzmer, R.; Stroyakovskiy, D.; Gogas, H.; Robert, C.; Lewis, K.; Protsenko, S.; Pereira, R.P.; Eigentler, T.; Rutkowski, P.; Demidov, L.; et al. Atezolizumab, vemurafenib, and cobimetinib as first-line treatment for unresectable advanced BRAFV600 mutationpositive melanoma ( IMspire150): Primary analysis of the randomised, double-blind, placebo-controlled, phase 3 trial. Lancet 2020, 395, 1835-1844. [CrossRef]

33. Benson, J.D.; Chen, Y.-N.P.; Cornell-Kennon, S.A.; Dorsch, M.; Kim, S.; Leszczyniecka, M.; Sellers, W.R.; Lengauer, C. Validating cancer drug targets. Nat. Cell Biol. 2006, 441, 451-456. [CrossRef] 
34. Wang, L.; Zhang, S.; Yu, X.; Guo, C. Novel Poly(ADP-ribose) Polymerase-1 Inhibitor DDHCB Inhibits Proliferation of BRCA Mutant Breast Cancer Cell In Vitro and In Vivo through a Synthetic Lethal Mechanism. Chem. Res. Toxicol. 2020, 33, $1874-1881$. [CrossRef]

35. Murata, S.; Zhang, C.; Finch, N.; Zhang, K.; Campo, L.; Breuer, E.-K. Predictors and Modulators of Synthetic Lethality: An Update on PARP Inhibitors and Personalized Medicine. BioMed Res. Int. 2016, 2016, 1-12. [CrossRef] [PubMed]

36. Faloon, P.W.; Bennion, M.; Weiner, W.S.; Smith, R.A.; Wurst, J.; Weiwer, M.; Hartland, C.; Mosher, C.M.; Johnston, S.; Porubsky, P.; et al. A Small Molecule Inhibitor of the MITF Molecular Pathway. In Probe Reports from the NIH Molecular Libraries Program; National Library of Medicine: Bethesda, MD, USA, 2010.

37. Ahmad, T.; Eisen, T. Kinase Inhibition with BAY 43-9006 in Renal Cell Carcinoma. Clin. Cancer Res. 2004, 10, 6388S-6392S. [CrossRef]

38. Halaban, R.; Zhang, W.; Bacchiocchi, A.; Cheng, E.; Parisi, F.; Ariyan, S.; Krauthammer, M.; McCusker, J.P.; Kluger, Y.; Sznol, M. PLX4032, a selective BRAF V600E kinase inhibitor, activates the ERK pathway and enhances cell migration and proliferation of BRAF WT melanoma cells. Pigment. Cell Melanoma Res. 2010, 23, 190-200. [CrossRef]

39. Inman, G.J.; Wang, J.; Nagano, A.; Alexandrov, L.B.; Purdie, K.J.; Taylor, R.G.; Sherwood, V.; Thomson, J.; Hogan, S.; Spender, L.C.; et al. The genomic landscape of cutaneous SCC reveals drivers and a novel azathioprine associated mutational signature. Nat. Commun. 2018, 9, 1-14. [CrossRef] [PubMed]

40. Lee, C.S.; Bhaduri, A.; Mah, A.; Johnson, W.L.; Ungewickell, A.; Aros, C.J.; Nguyen, C.B.; Rios, E.J.; Siprashvili, Z.; Straight, A.; et al. Recurrent point mutations in the kinetochore gene KNSTRN in cutaneous squamous cell carcinoma. Nat. Genet. 2014, 46, 1060-1062. [CrossRef] [PubMed]

41. Giglia-Mari, G.; Sarasin, A. TP53 mutations in human skin cancers. Hum. Mutat. 2003, 21, 217-228. [CrossRef]

42. Nakazawa, H.; English, D.; Randell, P.L.; Martel, N.; Armstrong, B.K.; Yamasaki, H. UV and skin cancer: Specific p53 gene mutation in normal skin as a biologically relevant exposure measurement. Proc. Natl. Acad. Sci. USA 1994, 91, 360-364. [CrossRef]

43. Stransky, N.; Egloff, A.M.; Tward, A.D.; Kostic, A.D.; Cibulskis, K.; Sivachenko, A.; Kryukov, G.V.; Lawrence, M.S.; Sougnez, C.; McKenna, A.; et al. The Mutational Landscape of Head and Neck Squamous Cell Carcinoma. Science 2011, 333, 1157-1160. [CrossRef]

44. South, A.P.; Cho, R.J.; Aster, J.C. The double-edged sword of Notch signaling in cancer. Semin. Cell Dev. Biol. 2012, 23, 458-464. [CrossRef]

45. South, A.P.; Purdie, K.J.; Watt, S.A.; Haldenby, S.; Breems, N.Y.D.; Dimon, M.; Arron, S.T.; Kluk, M.J.; Aster, J.C.; McHugh, A.; et al. NOTCH1 Mutations Occur Early during Cutaneous Squamous Cell Carcinogenesis. J. Investig. Dermatol. 2014, 134, $2630-2638$. [CrossRef]

46. Cammareri, P.; Rose, A.M.; Vincent, D.F.; Wang, J.; Nagano, A.; Libertini, S.; Ridgway, R.A.; Athineos, D.; Coates, P.J.; McHugh, A.; et al. Inactivation of TGF $\beta$ receptors in stem cells drives cutaneous squamous cell carcinoma. Nat. Commun. 2016, 7, 12493. [CrossRef] [PubMed]

47. Lane, D.P. p53, guardian of the genome. Nat. Cell Biol. 1992, 358, 15-16. [CrossRef]

48. Sethi, N.; Dai, X.; Winter, C.G.; Kang, Y. Tumor-Derived Jagged1 Promotes Osteolytic Bone Metastasis of Breast Cancer by Engaging Notch Signaling in Bone Cells. Cancer Cell 2011, 19, 192-205. [CrossRef] [PubMed]

49. Rao, P.; Kadesch, T. The Intracellular Form of Notch Blocks Transforming Growth Factor $\beta$-Mediated Growth Arrest in Mv1Lu Epithelial Cells. Mol. Cell. Biol. 2003, 23, 6694-6701. [CrossRef] [PubMed]

50. Palomero, T.; Lim, W.K.; Odom, D.T.; Sulis, M.L.; Real, P.J.; Margolin, A.; Barnes, K.C.; O’Neil, J.; Neuberg, D.; Weng, A.P.; et al. NOTCH1 directly regulates c-MYC and activates a feed-forward-loop transcriptional network promoting leukemic cell growth. Proc. Natl. Acad. Sci. USA 2006, 103, 18261-18266. [CrossRef] [PubMed]

51. Ronchini, C.; Capobianco, A.J. Induction of Cyclin D1 Transcription and CDK2 Activity by Notchic: Implication for Cell Cycle Disruption in Transformation by Notchic. Mol. Cell. Biol. 2001, 21, 5925-5934. [CrossRef]

52. Joshi, I.; Minter, L.M.; Telfer, J.; Demarest, R.M.; Capobianco, A.J.; Aster, J.C.; Sicinski, P.; Fauq, A.; Golde, T.E.; Osborne, B.A. Notch signaling mediates G1/S cell-cycle progression in T cells via cyclin D3 and its dependent kinases. Blood 2009, 113, 1689-1698. [CrossRef]

53. Rangarajan, A.; Talora, C.; Okuyama, R.; Nicolas, M.; Mammucari, C.; Oh, H.; Aster, J.C.; Krishna, S.; Metzger, D.; Chambon, P.; et al. Notch signaling is a direct determinant of keratinocyte growth arrest and entry into differentiation. EMBO J. 2001, 20, 3427-3436. [CrossRef] [PubMed]

54. Sahlgren, C.C.; Gustafsson, M.V.; Jin, S.; Poellinger, L.; Lendahl, U. Notch signaling mediates hypoxia-induced tumor cell migration and invasion. Proc. Natl. Acad. Sci. USA 2008, 105, 6392-6397. [CrossRef]

55. Jin, S.; Hansson, E.M.; Tikka, S.; Lanner, F.; Sahlgren, C.; Farnebo, F.; Baumann, M.; Kalimo, H.; Lendahl, U. Notch Signaling Regulates Platelet-Derived Growth Factor Receptor- Expression in Vascular Smooth Muscle Cells. Circ. Res. 2008, 102, 1483-1491. [CrossRef]

56. Rodeck, U.; Jost, M.; DuHadaway, J.; Kari, C.; Jensen, P.J.; Risse, B.; Ewert, D.L. Regulation of Bcl-xL expression in human keratinocytes by cell-substratum adhesion and the epidermal growth factor receptor. Proc. Natl. Acad. Sci. USA 1997, 94, 5067-5072. [CrossRef] [PubMed]

57. Uribe, P.; Gonzalez, S. Epidermal growth factor receptor (EGFR) and squamous cell carcinoma of the skin: Molecular bases for EGFR-targeted therapy. Pathol.-Res. Pract. 2011, 207, 337-342. [CrossRef] 
58. Ang, K.K.; A Berkey, B.; Tu, X.; Zhang, H.-Z.; Katz, R.; Hammond, E.H.; Fu, K.K.; Milas, L. Impact of epidermal growth factor receptor expression on survival and pattern of relapse in patients with advanced head and neck carcinoma. Cancer Res. 2002, 62, 7350-7356.

59. Fogarty, G.; Conus, N.; Chu, J.; McArthur, G. Characterization of the expression and activation of the epidermal growth factor receptor in squamous cell carcinoma of the skin. Br. J. Dermatol. 2006, 156, 92-98. [CrossRef]

60. Kolev, V.N.; Mandinova, A.; Guinea-Viniegra, J.; Hu, B.; Lefort, K.; Lambertini, C.; Neel, V.; Dummer, R.; Wagner, E.F.; Dotto, G.P. EGFR signalling as a negative regulator of Notch1 gene transcription and function in proliferating keratinocytes and cancer. Nat. Cell Biol. 2008, 10, 902-911. [CrossRef] [PubMed]

61. Kalyankrishna, S.; Grandis, J.R. Epidermal Growth Factor Receptor Biology in Head and Neck Cancer. J. Clin. Oncol. 2006, 24, 2666-2672. [CrossRef] [PubMed]

62. Singh, D.; Attri, B.K.; Gill, R.K.; Bariwal, J. Review on EGFR Inhibitors: Critical Updates. Mini-Rev. Med. Chem. 2016, 16, 1134-1166. [CrossRef]

63. Bartkova, J.; Lukas, J.; Müller, H.; Strauss, M.; Gusterson, B.; Bartek, J. Abnormal patterns of D-type cyclin expression and G1 regulation in human head and neck cancer. Cancer Res. 1995, 55, 949-956.

64. Izzo, J.G.; A Papadimitrakopoulou, V.; Li, X.Q.; Ibarguen, H.; Lee, J.S.; Ro, J.Y.; El-Naggar, A.; Hong, W.K.; Hittelman, W.N. Dysregulated cyclin D1 expression early in head and neck tumorigenesis: In vivo evidence for an association with subsequent gene amplification. Oncogene 1998, 17, 2313-2322. [CrossRef]

65. Ikeguchi, M.; Sakatani, T.; Ueta, T.; Kaibara, N. Cyclin D1 expression and retinoblastoma gene protein (pRB) expression in esophageal squamous cell carcinoma. J. Cancer Res. Clin. Oncol. 2001, 127, 531-536. [CrossRef] [PubMed]

66. Baldin, V.; Lukas, J.; Marcote, M.J.; Pagano, M.; Draetta, G. Cyclin D1 is a nuclear protein required for cell cycle progression in G1. Genes Dev. 1993, 7, 812-821. [CrossRef] [PubMed]

67. Shapiro, G.I. Cyclin-Dependent Kinase Pathways As Targets for Cancer Treatment. J. Clin. Oncol. 2006, 24, 1770-1783. [CrossRef] [PubMed]

68. Lapenna, S.; Giordano, A. Cell cycle kinases as therapeutic targets for cancer. Nat. Rev. Drug Discov. 2009, 8, 547-566. [CrossRef] [PubMed]

69. Dowdy, S.F. Death of a Dogma: Cyclin D Activates Rb by Mono-Phosphorylation. In D-type Cyclins and Cancer; Hinds, P.W., Brown, N.E., Eds.; Springer International Publishing: Cham, Switzerland, 2018; pp. 133-147.

70. Bäckvall, H.; Asplund, A.; Gustafsson, A.; Sivertsson, Å.; Lundeberg, J.; Ponten, F. Genetic tumor archeology: Microdissection and genetic heterogeneity in squamous and basal cell carcinoma. Mutat. Res. Mol. Mech. Mutagen. 2005, 571, 65-79. [CrossRef]

71. Brown, V.L.; Harwood, C.A.; Crook, T.; Cronin, J.G.; Kelsell, D.P.; Proby, C.M. p16INK4a and p14ARF Tumor Suppressor Genes Are Commonly Inactivated in Cutaneous Squamous Cell Carcinoma. J. Investig. Dermatol. 2004, 122, 1284-1292. [CrossRef]

72. Rayess, H.; Wang, M.B.; Srivatsan, E.S. Cellular senescence and tumor suppressor gene p16. Int. J. Cancer 2011, 130, 1715-1725. [CrossRef]

73. Li, Y.; A Nichols, M.; Shay, J.W.; Xiong, Y. Transcriptional repression of the D-type cyclin-dependent kinase inhibitor p16 by the retinoblastoma susceptibility gene product $\mathrm{pRb}$. Cancer Res. 1994, 54, 6078-6082.

74. Takahashi, A.; Ohtani, N.; Yamakoshi, K.; Iida, S.-I.; Tahara, H.; Nakayama, K.; Nakayama, K.I.; Ide, T.; Saya, H.; Hara, E. Mitogenic signalling and the p16INK4a-Rb pathway cooperate to enforce irreversible cellular senescence. Nat. Cell Biol. 2006, 8, 1291-1297. [CrossRef]

75. Witkiewicz, A.K.; Knudsen, K.E.; Dicker, A.P.; Knudsen, E.S. The meaning of p16ink4aexpression in tumors. Cell Cycle 2011, 10, 2497-2503. [CrossRef]

76. Eymin, B.; LeDuc, C.; Coll, J.-L.; Brambilla, E.; Gazzeri, S. p14ARF induces G2 arrest and apoptosis independently of p53 leading to regression of tumours established in nude mice. Oncogene 2003, 22, 1822-1835. [CrossRef]

77. Mason, S.L.; Loughran, Ö.; La Thangue, N.B. p14ARF regulates E2F activity. Oncogene 2002, 21, 4220-4230. [CrossRef]

78. Ekhteraei-Tousi, S.; Mohammad-Soltani, B.; Sadeghizadeh, M.; Mowla, S.J.; Parsi, S.; Soleimani, M. Inhibitory Effect of Hsa-miR590-5p on Cardiosphere-derived Stem Cells Differentiation Through Downregulation of TGFB Signaling. J. Cell. Biochem. 2014, 116, 179-191. [CrossRef]

79. Cross, T.G.; Scheel-Toellner, D.; Henriquez, N.V.; Deacon, E.; Salmon, M.; Lord, J.M. Serine/Threonine Protein Kinases and Apoptosis. Exp. Cell Res. 2000, 256, 34-41. [CrossRef]

80. Imamura, Y.; Jin, L.; Grande, J.P.; Li, C.-Y.; Zheng, T.-R.; Erickson, L.A.; Lloyd, R.V. Analysis of TGF- $\beta$ and TGF- $\beta$-RII in thyroid neoplasms from the United States, Japan, and China. Endocr. Pathol. 1998, 9, 209-216. [CrossRef] [PubMed]

81. Muñoz-Maldonado, C.; Zimmer, Y.; Medová, M. A Comparative Analysis of Individual RAS Mutations in Cancer Biology. Front. Oncol. 2019, 9, 1088. [CrossRef] [PubMed]

82. Shu, L.; Wang, D.; Saba, N.F.; Chen, Z.G. A Historic Perspective and Overview of H-Ras Structure, Oncogenicity, and Targeting. Mol. Cancer Ther. 2020, 19, 999-1007. [CrossRef] [PubMed]

83. Fang, L.; Seki, A.; Fang, G. SKAP associates with kinetochores and promotes the metaphase-to-anaphase transition. Cell Cycle 2009, 8, 2819-2827. [CrossRef]

84. Bamford, S.; Dawson, E.; Forbes, S.; Clements, J.; Pettett, R.; Dogan, A.; Flanagan, A.; Teague, J.; A Futreal, P.; Stratton, M.R.; et al. The COSMIC (Catalogue of Somatic Mutations in Cancer) database and website. Br. J. Cancer 2004, 91, 355-358. [CrossRef] [PubMed] 
85. Durinck, S.; Ho, C.; Wang, N.J.; Liao, W.; Jakkula, L.R.; Collisson, E.A.; Pons, J.; Chan, S.-W.; Lam, E.T.; Chu, C.; et al. Temporal Dissection of Tumorigenesis in Primary Cancers. Cancer Discov. 2011, 1, 137-143. [CrossRef]

86. Christensen, J.G.; Burrows, J.; Salgia, R. c-Met as a target for human cancer and characterization of inhibitors for therapeutic intervention. Cancer Lett. 2005, 225, 1-26. [CrossRef]

87. Joffre, C.; Barrow, R.; Ménard, L.; Calleja, V.; Hart, I.R.; Kermorgant, S. A direct role for Met endocytosis in tumorigenesis. Nat. Cell Biol. 2011, 13, 827-837. [CrossRef] [PubMed]

88. Maina, F.; Panté, G.; Helmbacher, F.; Andres, R.; Porthin, A.; Davies, A.M.; Ponzetto, C.; Klein, R. Coupling Met to Specific Pathways Results in Distinct Developmental Outcomes. Mol. Cell 2001, 7, 1293-1306. [CrossRef]

89. Yasui, H.; Ohnishi, Y.; Nakajima, M.; Nozaki, M. Migration of oral squamous cell carcinoma cells are induced by HGF/c-Met signalling via lamellipodia and filopodia formation. Oncol. Rep. 2017, 37, 3674-3680. [CrossRef] [PubMed]

90. Ndolo, K.M.; An, S.J.; Park, K.R.; Lee, H.J.; Bin Yoon, K.; Kim, Y.-C.; Han, S.-Y. Discovery of an Indirubin Derivative as a Novel c-Met Kinase Inhibitor with In Vitro Anti-Tumor Effects. Biomol. Ther. 2019, 27, 216-221. [CrossRef]

91. Pourreyron, C.; Reilly, L.; Proby, C.; Panteleyev, A.; Fleming, C.; McLean, K.; South, A.P.; Foerster, J. Wnt5a Is Strongly Expressed at the Leading Edge in Non-Melanoma Skin Cancer, Forming Active Gradients, while Canonical Wnt Signalling Is Repressed. PLoS ONE 2012, 7, e31827. [CrossRef]

92. Aggarwal, B.B.; Sethi, G.; Ahn, K.S.; Sandur, S.K.; Pandey, M.K.; Kunnumakkara, A.B.; Sung, B.; Ichikawa, H. Targeting SignalTransducer-and-Activator-of-Transcription-3 for Prevention and Therapy of Cancer. Ann. N. Y. Acad. Sci. 2006, 1091, 151-169. [CrossRef]

93. Asem, M.S.; Buechler, S.; Wates, R.B.; Miller, D.L.; Stack, M.S. Wnt5a Signaling in Cancer. Cancers 2016, 8, 79. [CrossRef]

94. Uchida, D.; Kawamata, H.; Omotehara, F.; Nakashiro, K.-I.; Kimura-Yanagawa, T.; Hino, S.; Begum, N.-M.; Hoque, M.O.; Yoshida, H.; Sato, M.; et al. Role of HGF/c-met system in invasion and metastasis of oral squamous cell carcinoma cellsin vitro and its clinical significance. Int. J. Cancer 2001, 93, 489-496. [CrossRef]

95. Park, E.-J.; Choi, S.J.; Kim, Y.-C.; Lee, S.H.; Park, S.W.; Lee, S.K. Novel small molecule activators of $\beta$-catenin-mediated signaling pathway: Structure-activity relationships of indirubins. Bioorg. Med. Chem. Lett. 2009, 19, 2282-2284. [CrossRef] [PubMed]

96. Nam, S.; Buettner, R.; Turkson, J.; Kim, D.; Cheng, J.Q.; Muehlbeyer, S.; Hippe, F.; Vatter, S.; Merz, K.-H.; Eisenbrand, G.; et al. Indirubin derivatives inhibit Stat3 signaling and induce apoptosis in human cancer cells. Proc. Natl. Acad. Sci. USA 2005, 102, 5998-6003. [CrossRef]

97. Blanz, J.; Ehninger, G.; Zeller, K.P. The isolation and identification of indigo and indirubin from urine of a patient with leukemia. Res. Commun. Chem. Pathol. Pharmacol. 1989, 64, 145-156.

98. Kim, S.-H.; Choi, S.J.; Kim, Y.-C.; Kuh, H.-J. Anti-tumor activity of noble indirubin derivatives in human solid tumor models In Vitro. Arch. Pharmacal Res. 2009, 32, 915-922. [CrossRef]

99. Banerjee, K.; Resat, H. Constitutive activation of STAT3 in breast cancer cells: A review. Int. J. Cancer 2016, 138, 2570-2578. [CrossRef]

100. Kelly, G.L.; Strasser, A. Toward Targeting Antiapoptotic MCL-1 for Cancer Therapy. Annu. Rev. Cancer Biol. 2020, 4, $299-313$. [CrossRef]

101. Tsujimoto, Y.; Shimizu, S. Bcl-2 family: Life-or-death switch. FEBS Lett. 2000, 466, 6-10. [CrossRef]

102. Kharbanda, S.; Pandey, P.; Schofield, L.; Israels, S.; Roncinske, R.; Yoshida, K.; Bharti, A.; Yuan, Z.-M.; Saxena, S.; Weichselbaum, R.; et al. Role for Bcl-xL as an inhibitor of cytosolic cytochrome C accumulation in DNA damage-induced apoptosis. Proc. Natl. Acad. Sci. USA 1997, 94, 6939-6942. [CrossRef]

103. Chao, D.T.; Korsmeyer, S.J. BCL-2 FAMILY: Regulators of Cell Death. Annu. Rev. Immunol. 1998, 16, 395-419. [CrossRef]

104. Venkateswaran, N.; Conacci-Sorrell, M. MYC leads the way. Small GTPases 2017, 11, 86-94. [CrossRef] [PubMed]

105. Zimmerman, K.; Alt, F.W. Expression and function of myc family genes. Crit. Rev. Oncog. 1990, 2, 75-95. [PubMed]

106. E Nesbit, C.; Tersak, J.M.; Prochownik, E.V. MYC oncogenes and human neoplastic disease. Oncogene 1999, 18, $3004-3016$. [CrossRef] [PubMed]

107. Walz, S.; Lorenzin, F.; Morton, J.P.; Wiese, K.E.; Von Eyss, B.; Herold, S.; Rycak, L.; Dumay-Odelot, H.; Karim, S.; Bartkuhn, M.; et al. Activation and repression by oncogenic MYC shape tumour-specific gene expression profiles. Nat. Cell Biol. 2014, 511, 483-487. [CrossRef] [PubMed]

108. Lin, C.Y.; Lovén, J.; Rahl, P.B.; Paranal, R.M.; Burge, C.B.; Bradner, J.E.; Lee, T.I.; Young, R.A. Transcriptional Amplification in Tumor Cells with Elevated c-Myc. Cell 2012, 151, 56-67. [CrossRef]

109. Nie, Z.; Hu, G.; Wei, G.; Cui, K.; Yamane, A.; Resch, W.; Wang, R.; Green, D.R.; Tessarollo, L.; Casellas, R.; et al. c-Myc Is a Universal Amplifier of Expressed Genes in Lymphocytes and Embryonic Stem Cells. Cell 2012, 151, 68-79. [CrossRef] [PubMed]

110. Kim, S.-A.; Kim, S.-W.; Chang, S.; Yoon, J.-H.; Ahn, S.-G. 5'-nitro-indirubinoxime induces G2/M cell cycle arrest and apoptosis in human KB oral carcinoma cells. Cancer Lett. 2009, 274, 72-77. [CrossRef]

111. Akiyama, Y.; Iizuka, A.; Kume, A.; Komiyama, M.; Urakami, K.; Ashizawa, T.; Miyata, H.; Omiya, M.; Kusuhara, M.; Yamaguchi, K. Effect of STAT3 inhibition on the metabolic switch in a highly STAT3-activated lymphoma cell line. Cancer Genom.-Proteom. 2015, 12, 133-142.

112. Sklirou, A.D.; Gaboriaud-Kolar, N.; Papassideri, I.; Skaltsounis, A.-L.; Trougakos, I.P. 6-bromo-indirubin-3'-oxime (6BIO), a Glycogen synthase kinase-3 $\beta$ inhibitor, activates cytoprotective cellular modules and suppresses cellular senescence-mediated biomolecular damage in human fibroblasts. Sci. Rep. 2017, 7, 11713. [CrossRef] 
113. Zhang, X.; Song, Y.; Wu, Y.; Dong, Y.; Lai, L.; Zhang, J.; Lu, B.; Dai, F.; He, L.; Liu, M.; et al. Indirubin inhibits tumor growth by antitumor angiogenesis via blocking VEGFR2-mediated JAK/STAT3 signaling in endothelial cell. Int. J. Cancer 2011, 129, 2502-2511. [CrossRef]

114. Lee, M.-J.; Kim, M.-Y.; Mo, J.-S.; Ann, E.-J.; Seo, M.-S.; Hong, J.-A.; Kim, Y.-C.; Park, H.-S. Indirubin-3'-monoxime, a derivative of a Chinese anti-leukemia medicine, inhibits Notch1 signaling. Cancer Lett. 2008, 265, 215-225. [CrossRef]

115. Newton, R.H.; Leverrier, S.; Srikanth, S.; Gwack, Y.; Cahalan, M.D.; Walsh, C.M. Protein Kinase D Orchestrates the Activation of DRAK2 in Response to TCR-Induced Ca2+ Influx and Mitochondrial Reactive Oxygen Generation. J. Immunol. 2010, 186, 940-950. [CrossRef]

116. Friedrich, M.L.; Cui, M.; Hernandez, J.B.; Weist, B.M.; Andersen, H.-M.; Zhang, X.; Huang, L.; Walsh, C.M. Modulation of DRAK2 Autophosphorylation by Antigen Receptor Signaling in Primary Lymphocytes. J. Biol. Chem. 2007, 282, 4573-4584. [CrossRef]

117. Matsumoto, M.; Miyake, Y.; Nagita, M.; Inoue, H.; Shitakubo, D.; Takemoto, K.; Ohtsuka, C.; Murakami, H.; Nakamura, N.; Kanazawa, H. A Serine/Threonine Kinase Which Causes Apoptosis-Like Cell Death Interacts with a Calcineurin B-Like Protein Capable of Binding Na+/H+ Exchanger. J. Biochem. 2001, 130, 217-225. [CrossRef] [PubMed]

118. Sanjo, H.; Kawai, T.; Akira, S. DRAKs, Novel Serine/Threonine Kinases Related to Death-associated Protein Kinase That Trigger Apoptosis. J. Biol. Chem. 1998, 273, 29066-29071. [CrossRef]

119. Cheng, X.; Merz, K.-H.; Vatter, S.; Christ, J.; Wölfl, S.; Eisenbrand, G. 7,7'-Diazaindirubin-A small molecule inhibitor of casein kinase 2 in vitro and in cells. Bioorg. Med. Chem. 2014, 22, 247-255. [CrossRef] [PubMed]

120. Ahmad, K.A.; Wang, G.; Unger, G.; Slaton, J.; Ahmed, K. Protein kinase CK2-A key suppressor of apoptosis. Adv. Enzym. Regul. 2008, 48, 179-187. [CrossRef] [PubMed] 